\title{
大型石炭貯蔵浮体システムの応答特性と荷役 稼働率に関する基礎的研究
}

\author{
惠藤 浩朗 1 - 敷田 曜 2 ・居駒 知樹 3 \\ - 増田 光一 4 -木原 寛明 2 \\ 1日本大学准教授 理工学部海洋建築工学科（广274-8501 千葉県船橋市習志野台 7-24-1） \\ E-mail: eto.hiroaki@nihon-u.ac.jp \\ 2 日本大学大学院 理工学研究科博士課程前期（干274-8501 千葉県船橋市習志野台 7-24-1） \\ E-mail: csmi16010@g.nihon-u.ac.jp,csyo13063@g.nihon-u.ac.jp \\ 3正会員 日本大学教授 理工学部海洋建築工学科（†274-8501 千葉県船橋市習志野台 7-24-1） \\ E-mail: ikoma.tomoki@nihon-u.ac.jp \\ 4 正会員 日本大学特任教授 理工学部海洋建築工学科（干274-8501 千葉県船橋市習志野台 7-24-1） \\ E-mail: masuda.koichi@nihon-u.ac.jp

\begin{abstract}
本研究では，大型石炭貯蔵浮体（LFTS）システムの応答特性と荷役稼働率について述べる. LFTS シ ステムの実現可能性を検討する上で，対象海域での荷役稼働率を把握することが重要である．LFTS は 50 万 $\mathrm{t}$ の石炭を積載可能であり, 石炭の積載状態により喫水が大きく変動し, それに伴い長周期変動波 漂流力を含めた波力や風荷重等が動摇に大きく影響を及ぼすことが考えられる. LFTS とバルクキャリ アは双方ともに大型構造物のため, 双方に作用する流体力は互いに影響を及ぼし合うことから 2 浮体間 の流体力学的相互干渉影響は無視できない。そこで本研究では流体力学的相互干渉影響を考慮した複合 外力下におけるバルクキャリアの運動応答を把握し, その結果をもとに荷役稼働率を算出し, LFTS シス テムの運用可否の把握に努めた。
\end{abstract}

Key Words : large floating, long-period oscillation, cargo handling efficiency

\section{1. 序論}

近年，日本の石炭輸入率は $90 \%$ を超えており，その輸 入量の $80 \%$ は，オーストラリアとインドネシアからの輸 入に依存している. 日本への第 2 の石炭輸出国であるイ ンドネシアはアジア太平洋地域の主な石炭供給国であり 現在，インドネシアは石炭輸出を増加させるために石炭 資源開発の促進を目的とする石炭政策を採用した ${ }^{1)}$. そ のためインドネシアの石炭輸送効率を高めることは, 関 連諸国にとって重要な案件である. しかしインドネシア の石炭の主要な採掘場所である東カリマンタンのマーカ ム川河口は, 沿岸部の海底が遠浅な地形であり, バルク キャリアが容易に接岸できない.そのためカリマンタン 島では，沖合に停泊寸るバルクキャリアにバージが接舷 し沖荷役により石炭を積載している．しかしこの輸送方 法ではバルクキャリアが満載になるまでに 1 週間程度を 要し，またバージによる石炭運搬は天候に大きく影響を 受ける. そこで本研究では図-1 に示寸沖合において大量 の石炭を貯蔵可能な LFTS を提案する. 図-2 に示寸よう に LFTS は陸域より約 $10 \mathrm{~km}$ 離れた位置に設置され, 陸
域からバージで運ばれる石炭を貯蔵し, 貯蔵された石炭 をバルクキャリアへ効率的に積み出寸施設である.これ によりバルクキャリアへの石炭の積み出しに要する時間

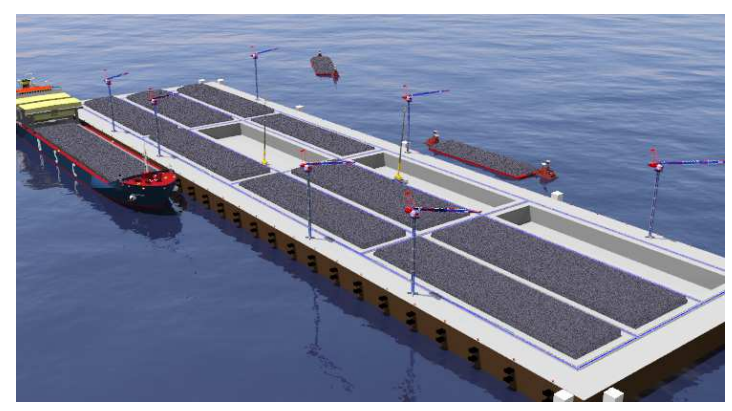

図-1 LFTS システムのイメーシ泪

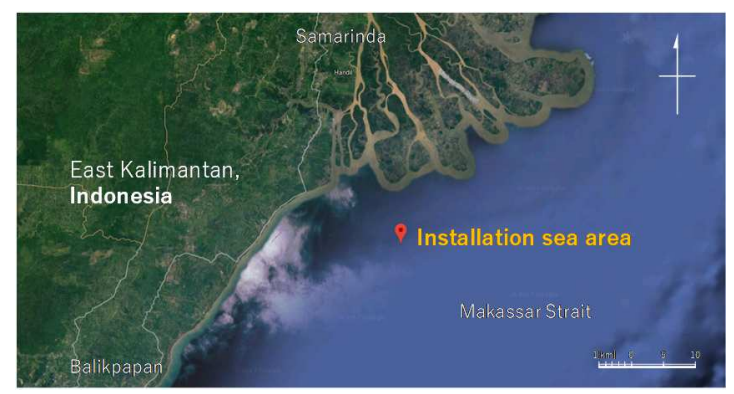

図-2 LFTS システムの設置海域 
を大幅に短縮し，稼働率の向上と収益性の向上が期待さ れる. LFTS は浮体規模が大きく, 非線形波浪外力の長周 期変動波漂流力や風荷重の長周期成分と共振する可能性 がある．また LFTS に接舷するバルクキャリアは大型構 造物であり, 双方の浮体の流体力学的相互干渉影響は無 視できない. そこで本研究では LFTS とバルクキャリア の流体力学的相互干渉影響や係留系の非線形性を含めた バルクキャリアの波浪中応答を解析し，その運動応答特 性を把握するとともに，設置海域の海象条件下で LFTS システムが運用可能であるか，荷役稼働率をもとに把握 することを目的として研究を行った.

\section{LFTS の概要}

本研究においては, LFTS がバルクキャリア 5 隻分 $(50$ 万t）の石炭を積載できるように設計した．また LFTS の 規模はバルクキャリア 2 隻が同時に接舷して作業できる ように $590 \mathrm{~m} \times 160 \mathrm{~m}$ と設定した. LFTS とバルクキャリ アの諸元を表-1 に示寸. LFTS の浮体上部には石炭を品 質ごとに分けて積載するための隔壁が配置されており， その隔壁上部にはベルトコンベアが設置されているため, クレーンの稼働範囲を気にすることなく石炭を自由に積 載可能である．また図-1 に示寸ようにバルクキャリアと 石炭バージが接舷する場所を分けることで荷役作業を同 時に実施可能な施設とした．LFTS の喫水は石炭の積載 量に応じて大きく変化し，その大きさは最大で $8 \mathrm{~m}$ 程度 にも達する，そのため，喫水の変化に伴う運動応答特性 や荷役稼働率の把握が必要である。 そこで本研究では空 荷状態と満載状態の 2 つの積載状態を設定した.

表-1ＬFTS とバルクキャリアの規模

\begin{tabular}{c|c|c|c}
\hline \multicolumn{4}{c}{ LFTS } \\
\hline Length & $590.0[\mathrm{~m}]$ & Width & $160.0[\mathrm{~m}]$ \\
\hline Draft & \multicolumn{3}{c}{ Empty : $1.8[\mathrm{~m}] /$ Full $: 7.0[\mathrm{~m}]$} \\
\hline \multicolumn{4}{c}{ Bulk Carrier } \\
\hline Length & $291.0[\mathrm{~m}]$ & Width & $45.0[\mathrm{~m}]$ \\
\hline Draft & Empty : $8.0[\mathrm{~m}] /$ Full : $16.0[\mathrm{~m}]$ \\
\hline \multicolumn{3}{c}{ Water depth } & $30.0[\mathrm{~m}]$ \\
\hline
\end{tabular}

\section{3. 研究手法}

\section{(1) 数值解析のプロセス}

まず LFTS システムとして LFTS とバルクキャリア双 方の運動応答特性を把握する必要がある。そして，LFTS とバルクキャリアの流体力学相互干渉影響を考慮したバ ルクキャリアの運動応答を算出し，LFTS システムとし
ての荷役稼働率を計算する。しかし LFTS のサイズはと ても大きく，また高い剛性を有する，そのため LFTS の 運動応答は小さいと予測される. そこで本研究では LFTS の運動応答は 0 と仮定した。

\section{（2）ラディエーション流体力と 1 次波強制力}

LFTS と係留されたバルクキャリア間の流体力学的相 互干渉影響は，それぞれの浮体のラディエーション流体 力，波強制力，そして運動応答に影響を与える. 本研究 ではラディエーション流体力，波強制力の解析は，弱非 線形と仮定したポテンシャル理論を適用した。

$<$ Radiation 問題 $>$

大型浮体とそれに係留された浮体間の流体力学的相互 干渉影響を考慮したのラディエーション問題では，前述 の仮定から大型浮体は固定物体として扱った.

また非線形応答である長周期動摇の周波数に対応する ラディエーション流体力は対応する線形流体力を用いた

$<$ Diffraction 問題 $>$

2 つの浮体が固定された状態の境界値問題が解かれる ことで，波強制力は各々の浮体の圧力積分で求まる。ま た波強制力に関する 1 次の全速度ポテンシャル $\varphi^{(1)}$ は(1) 式のように定義できる．浮体に作用する 1 次波強制力の 周波数伝達関数 $H_{i}^{(1)}(\omega)$ は (2)式のように与えられる.

$$
\varphi^{(1)}=-i \omega\left[a\left(\varphi_{0}^{(1)}+\varphi_{7}^{(1)}\right)\right]
$$

ただし， $a$ : 波振幅， $\omega$ : 円周波数， $\varphi_{0}^{(1)}: 1$ 次の入射波 ポテンシャル, $\varphi_{7}^{(1)}: 1$ 次の散乱波ポテンシャル

速度ポテンシャルの解法には三次元特異点分布法 2)を 適用した.

$$
H_{i}^{(1)}(\omega)=\rho a \omega^{2} \iint_{S_{H}}\left(\varphi_{0}^{(1)}+\varphi_{7}^{(1)}\right) n_{i} d s
$$

ただし, $\rho$ : 流体密度, $n_{i}$ : 各モードの法線ベクトル, $S_{H}$ : 物体表面の境界

1 次のインパルス応答関数 $h_{i}^{(1)}(\tau)$ は $H_{i}^{(1)}(\omega)$ を用いて (3)式で表される.

$$
h_{i}^{(1)}(\tau)=\operatorname{Re}\left[\frac{1}{2 \pi} \int_{-\infty}^{\infty} H_{i}^{(1)}(\omega) e^{i \omega \tau} d \omega\right]
$$

そのため 1 次波強制力の時系列はインパルス応答関数 と波変位の㽝み込み積分により(4)式で表される.

$$
F_{i}^{(1)}(t)=\int_{-\infty}^{\infty} h_{i}^{(1)}(\tau) \zeta(t-\tau) d \tau
$$

ただし, $F_{i}^{(1)}(\mathrm{t}): 1$ 次波強制力, $\zeta(t)$ : 入射波の時系列

\section{（3）波漂流力}

非線形波浪外力である波漂流力は係留系と同調し長周 期動摇を引き起こす可能性がある．本研究では波漂流力 
も考慮する必要がある. 波漂流力は 2 次の差周波数成分 により表わされ，それは物体表面上の直接圧力積分によ り求められる. その際，波漂流力は定常波漂流力と変動 波漂流力を含む. 次に波強制力の時間領域での取り扱い について考える. 時間領域での波強制力は，フーリエ変 換の関係を用いて周波数領域での波強制力の応答関数と 波振幅との畳み込夕関数で表現される. 2 次の差成分（波 漂流力）の伝達関数 $H_{j}^{(2)}\left(\omega_{1}-\omega_{2}\right)$ は, 1 次運動応答をそ の平均位置周りで捸動展開を行う。そして, 瞬時の没水 面に作用する流体圧を積分することで(5)式で表される.

$$
\begin{aligned}
& H_{i}^{(2)}\left(\omega_{1}-\omega_{2}\right)=-\frac{\rho}{4} \int_{W L} \eta_{R_{1}}^{(1)} \eta_{R_{2}}^{(1)^{*}} n_{i_{W L}} d l \\
& +\frac{\rho}{4} \iint_{S_{H}} \nabla \phi_{1}^{(1)} \nabla \phi_{2}^{(1)^{*}} n_{i} d s \\
& +\frac{i \rho \omega_{2}}{2} \iint_{S_{H}} \vec{X}_{1}^{(1)} \nabla \phi_{2}^{(1)^{*}} n_{i} d s+\frac{m \omega_{1}}{2} \vec{X}_{G} \\
& \quad \times \vec{\alpha}_{2}^{(1)^{*}} \\
& \quad-i \rho\left(\omega_{1}-\omega_{2}\right) \iint_{S_{H}} \phi_{0}^{(2)}\left(\omega_{1}-\omega_{2}\right) n_{i} d s
\end{aligned}
$$

ただし, $\eta_{R}^{(1)}$ : 相対水位， $\phi^{(1)}$ : ラディエーション流体力 を含めた 1 次の全速度ポテンシャル， $\phi_{0}^{(2)}: 2$ 次の入射 波ポテンシャル, $\vec{X}_{1}^{(1)}$ : 浮体上の任意の点の 1 次変位ベ クトル, $\vec{\alpha}^{(1)}: 1$ 次の回転角ベクトル, $\vec{X}_{G}$ : 浮体重心の 1 次変位ベクトル, $m$ : 浮体質量, $*$ : 複素共役

2次のインパルス応答関数 $h_{i}^{(2)}\left(\tau_{1}, \tau_{2}\right)$ は(6)式で表される.

$$
\begin{aligned}
h_{i}^{(2)}\left(\tau_{1}, \tau_{2}\right)=\operatorname{Re}[ & {\left[\frac { 1 } { 4 \pi ^ { 2 } } \int _ { - \infty } ^ { \infty } \int _ { - \infty } ^ { \infty } H _ { i } ^ { ( 2 ) } \left(\omega_{1}\right.\right.} \\
& \left.\left.-\omega_{2}\right) e^{i\left(\omega_{1} \tau_{1}-\omega_{2} \tau_{2}\right)} d \omega_{1} d \omega_{2}\right]
\end{aligned}
$$

そのため 2 次波強制力の時系列 $F_{i}^{(2)}(\mathrm{t})$ は, インパルス応 答関数と波変位との畳み込み積分により(7)式に示寸.

$F_{i}^{(2)}(t)=\int_{-\infty}^{\infty} h_{i}^{(2)}\left(\tau_{1}, \tau_{2}\right) \zeta\left(t-\tau_{1}\right) \zeta\left(t-\tau_{2}\right) d \tau_{1} d \tau_{2}$

ただし, $F_{i}^{(2)}(\mathrm{t}): 2$ 次波強制力

\section{（4）風荷重}

$10 \mathrm{~m}$ 高さの全風速 $u_{10}(t)$ が浮体全体に作用する風速と 仮定し, 風荷重は(8), (9)式で算定する.

$$
\begin{aligned}
F_{w_{i}}(t) & =\frac{1}{2} \rho_{a}\left(A_{W} \cos ^{2} \theta_{W}\right. \\
& \left.+B_{W} \sin ^{2} \theta_{W}\right) u_{10}(t)^{2} C_{W_{i}} \quad(i=1 \sim 3) \\
F_{w_{i}}(t) & =\frac{1}{2} \rho_{a}\left(A_{W} \cos ^{2} \theta_{W}\right. \\
& \left.+B_{W} \sin ^{2} \theta_{W}\right) u_{10}(t)^{2} C_{W_{i}} \cdot L_{W_{i}} \quad(i=4 \sim 6)
\end{aligned}
$$

ただし, $\rho_{a}$ 空気密度, $A_{W}$ : 海面上正面投影面積, $B_{W}$ : 海面上側面投影面積, $\theta_{W}$ : 風の入射方向, $C_{W}$ : 抗力係数

(風力係数), $L_{W}$ : 重心と風圧中心間距離

\section{(5) 潮流力}

潮流は変動も少なく一般的に潮流は定常流として扱わ れる. 本研究では潮流速を定常流速 $u_{C}(t)$ とし, 潮流力 $F_{C_{i}}(t)$ は風荷重と同様に(10), (11)式により算定される.

$$
\begin{array}{r}
F_{C_{i}}(t)=\frac{1}{2} \rho\left(A_{C} \cos ^{2} \theta_{C}+B_{C} \sin ^{2} \theta_{C}\right) u_{C}(t)^{2} C_{D_{i}} \\
(i=1 \sim 3) \\
F_{C_{i}}(t)=\frac{1}{2} \rho\left(A_{C} \cos ^{2} \theta_{C}+B_{C} \sin ^{2} \theta_{C}\right) u_{C}(t)^{2} C_{D_{i}} \\
\cdot L_{D_{i}} \quad(i=4 \sim 6)
\end{array}
$$

ただし， $A_{C}$ : 没水部正面投影面積， $B_{C}$ : 没水部側面投影 面積, $\theta_{C}$ : 潮流の入射方向, $C_{D}$ : 抗力係数, $L_{D}$ : 重心と 潮流速の中心間距離

\section{(6) 運動応答}

運動方程式はメモリー影響関数を用いた微積分運動方 程式で表す C.I (Convolution Integral) 法により時間領域で 解く. 外力と係留力は非線形性を有するため, 固有周期 に応じ共振現象も含めた C.I 法が応答解析に用いられる. C.I 法を用いた時間領域の運動方程式は(12)式となる.

$$
\begin{aligned}
& \sum_{j=1}^{6}\left[\left\{m_{i j}+A_{m_{i j}}(\infty)\right\} \ddot{\xi}_{J}(t)\right. \\
& +\int_{0}^{t} K_{i j}(t-\tau) \dot{\xi}_{j}(\tau) d \tau+B_{W_{i j}} \dot{\xi}_{J}(t) \\
& +N_{V_{i j}} \xi_{J}(t)\left|\dot{\xi}_{J}(t)\right| \\
& \left.+C_{i j} \xi_{j}(t)+G_{i}\left\{\xi_{1}(t), \xi_{2}(t), \cdots \xi_{6}(t)\right\}\right] \\
& =F_{i}^{(1)}(t)+F_{i}^{(2)}(t)+F_{W_{i}}(t)+F_{C_{i}}(t) \\
& \quad(i=1 \sim 6)
\end{aligned}
$$

ただし, $m_{i j}$ : 浮体の広義の質量, $A_{m_{i j}}$ : 周波数無限大で の付加質量, $K_{i j}(t)$ : メモリ一影響関数, $B_{W_{i j}}$ : 波漂流減 衰係数, $N_{V_{i j}}$ : 粘性減衰力係数, $C_{i j}$ : 静的復元力係数, $G_{i}$ : 係留力, $\ddot{\xi}_{J}$ : 浮体の加速度振幅, $\dot{\xi}_{J}$ : 浮体の速度振幅, $\xi_{j}:$ 浮体の運動振幅

\section{（7） 荷役稼働率の算出方法}

荷役稼働率の定義は「係留施設前面において，年間を 通じ $97.5 \%$ 以上の停泊又は係留日数を可能とする静榣度 を確保することを原則」とされ ${ }^{3)}$, 船舶の規模に応じ荷 役許容動摇量は設定される。しかし長周期動摇により荷 役障害が発生する場合もあり, 浮体の長周期動摇の把握 は重要である ${ }^{4}$. 本研究ではバルクキャリアの運動応答 が係留系の影響を強く受けると予想されるため，ロープ で LFTS に係留されたバルクキャリアの流体力学的相互 干渉影響を考慮した数値シミュレーションを用い荷役稼 働率を算定する．有義波高，有義波周期別ごとの船舶の 波浪中応答解析結果と，船種，船型，波周期別に規定さ れる係留船舶の荷役許容動摇量を用い，荷役許容波高を 算出する 5). ばら積船の荷役許容動摇量を表-2 に示す. 
表-2 ばら積み船の荷役許容動摇量 6).

\begin{tabular}{c|c|c|c|c|c}
\hline $\begin{array}{c}\text { Surge } \\
{[\mathrm{m}]}\end{array}$ & $\begin{array}{c}\text { Sway } \\
{[\mathrm{m}]}\end{array}$ & $\begin{array}{c}\text { Heave } \\
{[\mathrm{m}]}\end{array}$ & $\begin{array}{c}\text { Roll } \\
{[\mathrm{rad}]}\end{array}$ & $\begin{array}{c}\text { Pitch } \\
{[\mathrm{rad}]}\end{array}$ & $\begin{array}{c}\text { Yaw } \\
{[\mathrm{rad}]}\end{array}$ \\
\hline \pm 1.0 & \pm 1.0 & \pm 0.5 & \pm 3.0 & \pm 1.0 & \pm 1.0 \\
\hline
\end{tabular}

数值計算から得られる各有義波周期での各動摇量の最 大值と有義波高の関係を回帰分析し，最大動摇量を荷役 許容動摇量以下とする波高として荷役許容波高は求めら れる. そして,荷役許容波高と設置海域における波高と周 期の結合出現確率より荷役稼働率を算出する. 稼働率は (13)式により算定することができる.

$$
P=\int_{0}^{H_{\infty}} \int_{0}^{T_{\infty}} Q(H, T) W(H, T) d H d T
$$

ただし, $\mathrm{P}$ : 荷役稼働率, $\mathrm{H}_{\infty}$ : 有義波高の最大值, $\mathrm{T}_{\infty}$ : 有義周期の最大值, $\mathrm{Q}(\mathrm{H}, \mathrm{T})$ : 波の出現確率, $\mathrm{W}(\mathrm{H}, \mathrm{T})$ : 荷 役可否

\section{4. 計算条件}

LFTS システムの荷役稼働率を計算するための計算条 件は石炭エネルギーセンターの調査資料 7)を参考に乾季 (5月〜10月) と雨季 (11 月〜4 月) に分けて決定した. シーズンごとの波や風，潮流の入射角や LFTS システム の配置状況を図-3に示す．またバルクキャリアは図-4に 示すように防舷材と係留索により LFTS に係留される. 具体的には LFTS とバルクキャリアは 12 本の $\phi 72 \mathrm{~mm} の$ ロープで繋がれ，その先にはテールロープとして $\phi 44 \mathrm{~mm}$

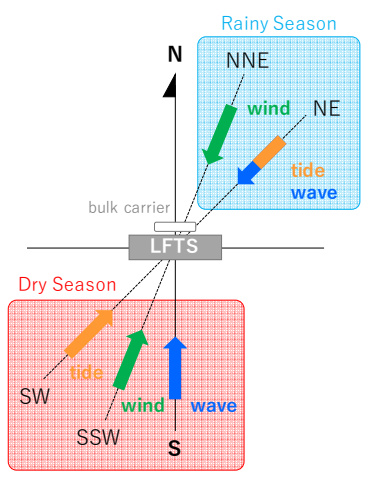

a) Case1

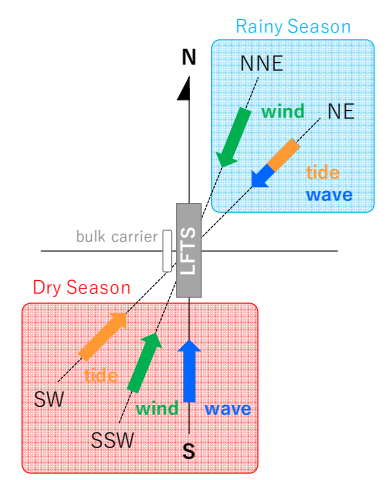

b) Case 2
図-3ＬFTS システムの設置状態

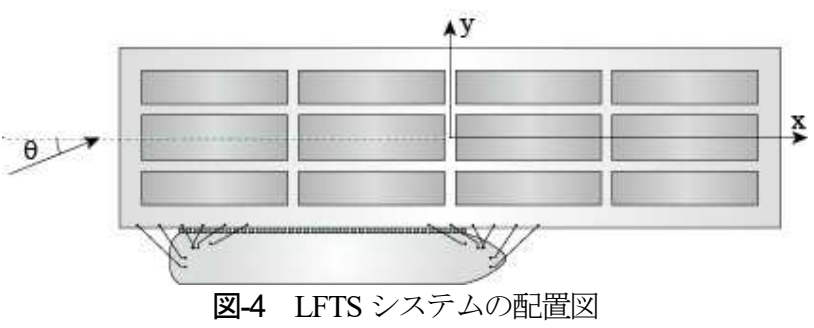

土木学会論文集B3 海洋開発), Vol. 74, No. 2, I_964 I_969, 2018.

の HMPE ロープを設けた．また LFTS と船舶との間には 最大反力 $545 \mathrm{kN}$ の防舷材を $5 \mathrm{~m}$ おき 57 基に配置した.

風や潮流の条件として, 乾季と雨季の平均值 (通常時) と最大值 (暴風時) を用いた。 波条件は乾季と雨季ごと に最大の有義波高とそれに対応する有義波周期を用いた。 乾季と雨季の通常時と暴風時における東カリマンタン島 沿岸の自然環境条件を表-3に示す．また不規則波のスペ クトルには Bret Schneider-光易型スペクトルを採用した.

表-3＼cjkstart東カリマンタン島の自然環境条件

\begin{tabular}{c|c|c|c|c}
\hline & \multicolumn{2}{|c|}{ 乾季 } & \multicolumn{2}{c}{ 雨季 } \\
\hline & 通常 & 暴風 & 通常 & 暴風 \\
\hline 有義波高 $[\mathrm{m}]$ & \multicolumn{2}{|c|}{2.30} & \multicolumn{2}{c}{0.99} \\
\hline 有義波周期 $[\mathrm{s}]$ & \multicolumn{2}{|c|}{5.90} & \multicolumn{2}{c}{8.20} \\
\hline 風速 $[\mathrm{m} / \mathrm{s}]$ & 4.30 & 8.37 & 2.39 & 5.98 \\
\hline 潮流速 $[\mathrm{m} / \mathrm{s}]$ & 0.28 & 0.68 & 0.09 & 0.70 \\
\hline
\end{tabular}

\section{5. 運動応答特性}

バルクキャリアの運動応答特性を把握するために Case2 の雨季の自然環境条件で応答を解析した. surge と sway, heave の時系列応答の結果をそれぞれ図-5～7 に示 す.また入射波のスペクトルを図- 8 , surge の応答スペク トルを図-9に示す.

図-5,6より surge 方向の応答量が大きい值で得られた. これは 2 次の波力の長周期成分と係留システムとの共振

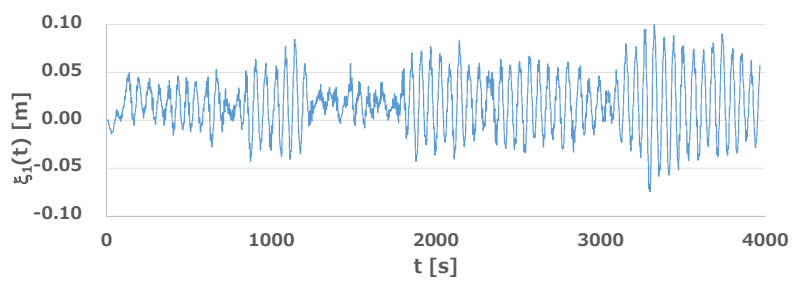

図-5 surge $の$ 時系列応答

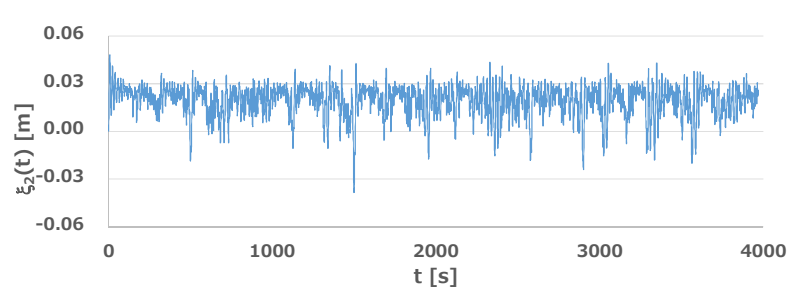

図-6 sway の時系列応答

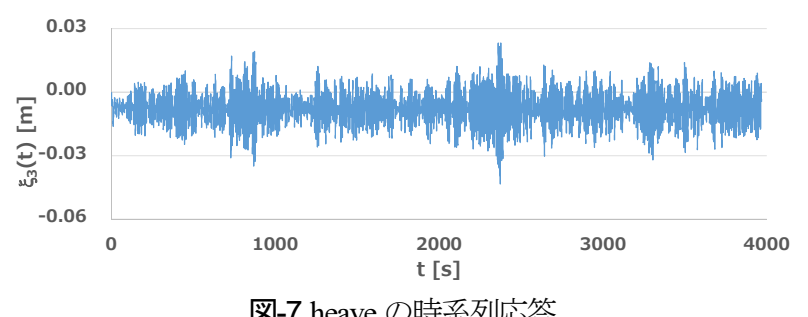

図-7 heave $の$ 時系列応答 


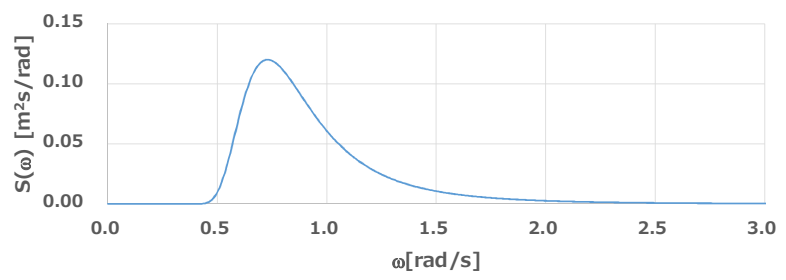

図-8 入射波のパワースペクトル

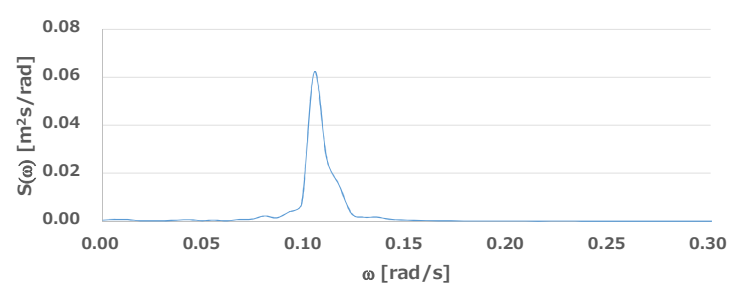

図-9 surge の応答スペクトル

現象に起因すると考えられる. また図-7 より heave 方向 の時系列応答は, surge 方向や sway 方向と比較して小さ い值で得られることが確認された. 図-8，9を比較すると 入射波と応答のスペクトルはそれぞれ異なる值でピーク を向かえている. また応答スペクトルの結果より約 57 秒 $(0.11 \mathrm{rad} / \mathrm{s})$ の長周期動摇の発生が確認される.

\section{6. 荷役稼働率}

荷役稼㗢率の算定には，水平方向と鉛直方向の長周期 動摇が加味された運動応答を用いて, LFTS システムの 荷役稼働率を設置状態や石炭の積載状態，シーズン，自 然環境条件を変化させて実施した．荷役稼働率の計算結 果を表-4に示寸。

表-4ＬFTS システムの荷役稼働率

\begin{tabular}{c|c|c|c|c|c}
\hline \multicolumn{2}{c|}{ 風速 } & \multicolumn{2}{|c|}{ 通常 } & \multicolumn{2}{c}{ 暴風 } \\
\hline \multirow{2}{*}{ 喫水状態 } & 空荷 & 満載 & 空荷 & 満載 \\
\hline \multirow{2}{*}{ Case1 } & 乾季 & $21.7 \%$ & $26.0 \%$ & $21.7 \%$ & $26.0 \%$ \\
\cline { 2 - 6 } & 雨季 & $41.2 \%$ & $79.8 \%$ & $36.1 \%$ & $85.8 \%$ \\
\hline \multirow{2}{*}{ Case2 } & 乾季 & $97.7 \%$ & $98.7 \%$ & $18.7 \%$ & $97.9 \%$ \\
\cline { 2 - 6 } & 雨季 & $100.0 \%$ & $75.4 \%$ & $100.0 \%$ & $75.3 \%$ \\
\hline
\end{tabular}

\section{(1) Case1 と Case2 による比較}

表-4 より Case1 より Case2 の方が，全体的に荷役稼働 率を満足する結果が得られた. Case 1 では LFTS とバル クキャリアの位置関係から sway の外力が支配的に作用 している. Sway の外力はバルクキャリアが LFTS に衝突 する方向に作用しているため応答量が大きくなったと考 察される。しかし Case2 では外力が受圧面積の小さい surge 方向に作用しているため, 長周期動摇が確認される ものの応答量は小さく，荷役稼働率を満足する結果が得
られた. これらの結果より, LFTS システムの設置状態は 荷役稼働率に大きく影響を及ぼすことが確認された。

\section{（2）喫水状態による比較}

石炭の積載状態の変化を想定し，満載時及び空荷時に おける荷役稼働率を計算した。満載時は没水部分が大き いため，波の影響を強く受ける．そのため，波の条件が 穏やかな雨季でも喫水が深いため波の影響を強く受け, 荷役稼働率は最大でも $85.8 \%$ しか得られなかった。空荷 時は乾舷面積が大きいため，風の影響を受けや寸い，し かし Case 2 の雨季ではバルクキャリアが LFTS の風下に 配置される状態となる。そのため，バルクキャリアが LFTS の影となり，バルクキャリアの受圧面積が小さく なることで風の影響が抑えられ，暴風時でも荷役稼働率 は満足された。

\section{（3） 通常時と暴風時の比較}

Case1 の雨季における通常時と満載時の運動応答の結 果を図-10，また応答スペクトルの結果を図-11 に示す. 一般的には暴風時の方が通常時と比較して荷役稼働率が 低下寸ると考えられるが Case 1 の雨季では暴風時の荷役 稼働率よりも通常時の方が低い值を示した。これは暴風 時の風速が高く，Case1 の配置ではバルクキャリアを LFTS に抑える方向に風荷重が作用し，図-10 の時系列運 動応答の結果からもバルクキャリアの動摇が抑えられた こと確認される．また暴風時よりも大きな応答量を示寸 通常時では，自然環境条件と係留システムの条件より図 -11 に示寸応答スペクトルにおいても低周波数の周波数 帯にピークが確認され，長周期動摇が確認された．その ため暴風時には動摇が抑制されたことと，通常時の条件 下で長周期動摇が生じたことから荷役稼働率が逆転する 值で得られたと考察される. Case2 の乾季における暴風 時の空荷時の荷役稼働率は風の影響を強く受けて $18.7 \%$

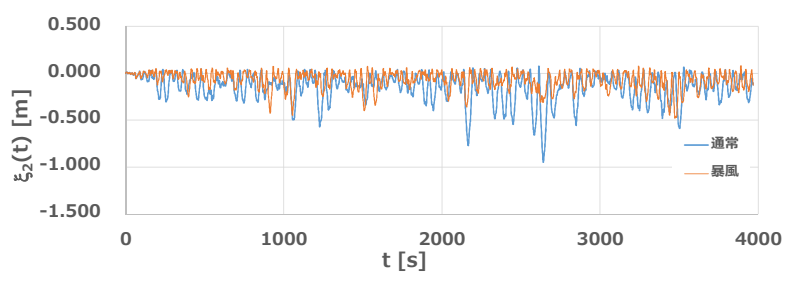

図-10 sway の通常時と暴風時の時系列運動応答

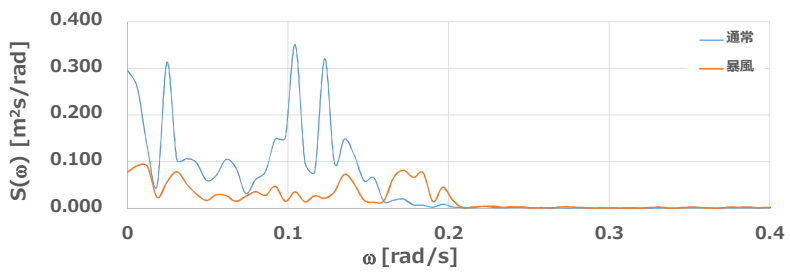

図-11 sway の通常時と暴風時の応答スペクトル 
と低い值で得られたが，Case2 はほぼ荷役稼働率が満足 する結果が得られた.

\section{7. 本結論}

本研究では以下の知見を得た

- LFTS システムの運動応答に関して，2 次の波力の長 周期成分と係留系が共振現象を引き起こし, 本計算条 件においては約 57 秒の長周期動摇が確認された.

- 東カリマンタン島の設置海域の海象データより, 暴風 時の風速は通常時の約 2 倍であった. また空荷時には 乾舷面積が広いため風の影響を強く受け, 荷役稼働率 を下げる要因となった。

- 長周期変動波漂流力を考慮することで, 今回，設定さ れた係留条件と通常時の波浪条件では水平方向や鉛 直方向の長周期動摇が発生し, 荷役稼働を下げる要因 となり, 通常の荷役稼働の方が暴風時よりも低い結果 を示した。

- LFTS システムの設置位置による荷役稼働率を比較す ると, バルクキャリアが LFTS の風下に設置さている 状態であれば荷役効率は満足され，LFTS システムは 設置が適切であれば十分に運用可能であることが確 認された.

今後, LFTS システムの係留系の検討やLFTS の運動を 考慮した状態での応答解析を実施し荷役稼働率を求め,
LFTS システムの実現に向けた検討を実施する.

\section{参考文献}

1) 三室戸義光，杉内信三：インドネシア・カリマ ンタンにおける石炭輸送最適化調査，一般財団 法人日本エネルギー経済研究所，2001.

2) 増田光一，大澤弘敬 : 沿岸海域に弛緩係留された浮 遊式建築物の運動及び係留索張力の予測法に関す る研究 (第2報)，日本建築学会構造系論文集，第471 号，p.193-202，1995年5月

3）国土交通省港湾局監修 : 港湾の施設の技術上の基 準・同解説，上巻， 2007

4) 財団法人 沿岸技術研究センター : 港内長周期波影 響評価マニュアル，2004

5) 上田茂，白石悟，大島弘之，浅野恒平 : 係岸船舶の 動摇に基づく許容波高及ひ稼働率，港湾技術技研資 料N0.779, 港湾空港技術研究所

6) PIANC : Criteria for movements of moored ships in harbours -A practical guide-, Report of Working Group No.24 of the Permanent Technical Committee II, 1995

7) 財団法人 石炭エネルギーセンター：平成22年度イ ンフラ・システム輸出促進調査等事業（インドネシ ア石炭資源の有効活用に資する洋上貯炭出荷及び 輸送効率化に係る調査)，2011.8

(2018.2.8 受付)

\title{
A FUNDAMENTAL STUDY ON MOTION CHARACTERISTICS AND CARGO HANDLING EFFICIENCY OF THE LARGE-SCALE FLOATING COAL TRANSSHIPMENT STATION
}

\author{
Hiroaki ETO, Yoh SHIKITA, Tomoki IKOMA, \\ Koichi MASUDA and Hiroaki KIHARA
}

This paper describes the motion characteristics and cargo handling efficiency of the Large-Scale Floating Coal Transshipment Station (LFTS). In considering feasibility of the LFTS system, it is important to know the cargo handling operation rate in the target area. LFTS can load 500,000 tons of coal and the draft will fluctuate greatly depending on the loading condition of coal. Accordingly, it is conceivable that wind load and the wave force including the slowly varying wave drift force affect the fluctuation greatly affect the fluctuation. Also, LFTS and bulk carrier are large-scale structures, the fluid forces acting on both affect each other, so the influence of hydrodynamic mutual interference between two floating bodies cannot be ignored. In this study, Grasp the motion response of bulk carrier under composite external force considering influence of hydrodynamic mutual interference, Based on the results, cargo handling efficiency was calculated, and the operating status of the LFTS system was grasped. 